\title{
Capability of Jordanian Industrial Shareholding Companies to Apply Target Costing System
}

\author{
Abed El-Rahman kh. Al-Dalabeeh ${ }^{1}$ \\ ${ }^{1}$ Accounting Department, Faculty of Finance and Business Administration, AL Al-bayt University, Mafraq, \\ Jordan \\ Correspondence: Abed El- Rahman kh. Al- Dalabeeh, Accounting Department, Faculty of Finance and Business \\ Administration, AL Al-bayt University, Mafraq, Jordan. E-mail: Dalabih75@yahoo.com
}

Received: July 5, 2012

Accepted: September 21, 2012

Online Published: October 23, 2012

doi:10.5539/ijbm.v7n21p124

URL: http://dx.doi.org/10.5539/ijbm.v7n21p124

\begin{abstract}
This study aims to identify the target costing system and its application in Jordanian industrial companies, and to what extent the companies apply cost reduction methods, also what are the obstacles prevent using target costing facing Jordanian companies, 50 of these companies were selected randomly and distribute a survey to the financial manager to answer the questionnaire items, the result showed that the companies have the ability target costing system as a method of reducing cost, The research recommended that there is a necessity to apply target costing system in an integral way in industrial companies.
\end{abstract}

Keywords: target costing, target price, target profit, cost reduction methods

\section{Introduction}

Due to increasing world wide competition and advanced technology used in production and attempt by industrial companies to satisfy customers by competitive goods (price and quality) in short time and to get project, target costing concept has come up to existence as a modern trend and system in industrial costs systems.

Target costing system is one of the most important systems used in managing costs in the stage preceding the production operation $\mathrm{s}$, which is due to this approach in affecting : production operation cycle, value chain analysis, continuous improvement), in added to its suitability to business environment, whereas the target costing concept appeared first in Japan on 1960, which was actually used there by $80 \%$ of big companies, in adding to the Japanese industries development of many costs systems and tools early available with many adjustment to them that suits changes in business that industrial companies may face.

\subsection{Problem of the Study}

Despite the scarce of natural resources in Jordan, a huge and confident development in industrial sector at the latest five years, because of attractive policy of foreign and gulf area investors to Jordan, which searching for new markets in near future, An increase rates in exports was noticed exceeding eighteen percent in 2009. For a development country as Jordan industrial sector in general and shareholding companies specifically faced the global financial crises strongly by notifying an increase in industrial shareholding companies recording one thousands and five hundreds industrial company.

So due to strong competition between companies and the reduction in its ability to affect prices and shifting its efforts to improve its capabilities in producing goods in competitive prices and qualities, and to have its customers satisfied in addition to paying attention to costs and take control over developing the product costs by increasing its quality and selling them with competitive price within a short time to get the targeted profit, so this study is interested in discover to what extent the Jordanian industrial companies apply target costing system in its cost management .

Based on the problem statement tries to answer the following questions:

1) Do the Jordanian industrial companies have the capability to apply target costing system.

2) Do the Jordanian industrial companies use cost reduction strategy

3) Do the Jordanian industrial companies facing administrative, organizational and accounting obstacles prevent using target costing system. 


\subsection{Importance of the Study}

The Study significant arises from the increase in global competition and keeping pace the Jordanian industrial companies with the new production operation and using target costing as a new system that helps industrial companies mangers in making strategically decisions as product cost and sales prices.

\subsection{Objectives of the Study}

This study came to achieve the following objectives:

- To determine the extent of which the Jordanian industrial companies capable to apply target costing system.

- To determine the extent of which the Jordanian industrial companies use cost reduction strategy

- To determine the extent of which the Jordanian industrial companies facing administrative, organizational and accounting obstacles prevent using target costing system.

\section{Conceptual Framework and Previous Studies}

\subsection{Previous Studies}

Target costing is defined as a cost management tool for making reduction a key focus throughout the life of a product (Horngren, Sundem and Stratton, 1997), and a cost management tool that planners use during product and process design to drive improvement efforts aimed at reducing the product's future manufacturing costs (Kaplan and Atkinson, 1998). It is also a "method for supporting competency through maintaining continuity factors for the establishment (quality, price and performance) within acceptable limitations for customers" (Pierce, 2002) and to manage future profits of the organization through adding target costing to the process of product development (Cooper \& Slagmudler, 2002), (Yook, 2005).

Notably, the aforementioned definitions take into consideration market conditions, competition and customer desires; which means that they take into consideration the outside perspective in determining costs. Therefore, enterprises need an approach in which production does not only depend on available resources, but also takes into consideration internal and external environments with prices acceptable for customers and achieving targeted market share. This was confirmed by (Lockamy, A \& Smith, W. I.) who highlighted the importance of adopting the target costing approach in supply chain management, considering that the aim is not only to reduce cost but also attain customer requirements under fixed costs (Lockamy \& Smith, 2000). Supply chain cost management is also used to create other domains of cost reduction and contribute to the redesign and restructure of products in a manner that allows for cost reduction. In this context, Pierre, B. (2002) defined target costing as a method for supporting competencies through maintaining continuity factors (quality, price and performance) in domains acceptable for customers; this shall be achieved by mechanisms such as value engineering and cost management among structures through the supply chain.

Two other concepts are essentially related to target costing: "target price", defined by Kato (1993) as "the estimated price for a product. It is considered the starting point for target costing efforts, determined by studying several factors of the market such as product quality and properties, and the price acceptable to customers, in addition to identifying the reactions of competitors towards that price. It appeared from the study by Cooper \& Slagmulder (1999) that the enterprise sets prices for its products so that they are close to those of competitors, and it may gradually raise or lower such prices according to customers' evaluation of the functions of its products compared to the products of competitors. The second concept is "target profit", defined by Kato as "the amount of profit which management seeks to achieve from a certain product, determined by a long-term or short-term earning plan which reflects the enterprise's strategic planning process". It appeared from the study by Cooper \& Slagmulder on Sony Electronics that this enterprise sets a gross profit margin for all products on the production line, and then divides the gross profit margin on products to reach the target profit for each product.

Target costing mainly aims to reduce costs, in addition to the following targets: (i) to satisfy customers' needs and requirements by offering advanced products with proper quality and prices (Ansari \& Jand, 1997), (ii) to achieve the goals of the enterprise's senior management of long-term earnings and competition in spite of economic and technological changes, and despite recurring market needs and internal pressure (Ansari \& Jand, 1997), and (iii) to create a balance between cost, price and invested capital. When target costing is applied in the production of a new product, the cost of such product is calculated by subtracting target profit from the sale price determined on the basis of market conditions and current capabilities of the enterprise. 


\subsection{Objectives of Target Costing}

Target costing has been developed and applied by major enterprises for several reasons including:

- Intensifying competition between enterprises has led owners and managers to search for new methods to maintain their presence and continuity in the market for the longest possible periods through offering products with less cost and better quality and technologies (Mills \& Schmidt, 1994).

- Industrial enterprises are no longer designing products for the purpose of better technologies; they are rather interested in designing products with required technologies (Morgan and P. Weerakoon).

- Pricing decisions for new products are becoming more difficult to make due to uncertainty surrounding decision environments. This has led enterprises to search for a system that studies internal and external environments of the product on a constant basis (Muharram, 1995).

- It shall minimize any increases in production costs by imposing spending limitations and avoiding pointless efforts (Boer \& Ettlie, 1992), (Wood, 1995).

Several studies have addressed the applications of target costing. Ibusuki \& Kaminski (2007) created a model of product development at the automobile industry through value engineering and cost targeting by developing the three stages of production (pre-production, planning and design) and applying value engineering. The research showed that the implementation of the model leads to reducing product costs and achieves quality that corresponds with the targeted market. The study by Swenson et al. (2003) aimed to identify the companies which most apply target costing in the United States through conducting a field survey of companies which apply this system. The study found that the leading five companies in applying target costing were Chrysler Group, Continental Teves, Caterpillar, Daimler and Boeing, which all demonstrated efficacy in applying target costing in managing costs and increasing opportunities for achieving profits. On the other hand, Dekker and Smidt (2003) conducted a survey study to identify the Dutch companies which adopted cost practices similar to the target costing notion in Japan. The study found that 19 companies out of 32 claim that they apply such practices under different names, and that cost reduction is the main reason for these companies to apply the practice. The study also showed that the biggest contribution to target costing application efforts came from planning and designing departments, while accounting departments had the weakest contribution to applying the target costing system. The study by Borgerams and Fridh (2003) sought to identify the extent to which Swedish companies apply target costing compared to other countries. The results showed that $16.5 \%$ of the study companies applied target costing. The lack of awareness was one of the reasons for the failure to apply this method, which could be attributed to companies' reluctance to adopt major methods which differ from those applied currently by most enterprises.

\subsection{Study Hypothesis}

Based on the earlier discussion and results from prior studies, hypotheses in the present can be formulated as below:

Hypothesis -1: "the Jordanian industrial companies have the capability to apply target costing system"

Hypothesis -2: "the Jordanian industrial companies use cost reduction strategy"

Hypothesis $-3: " t h e$ Jordanian industrial companies facing administrative, organizational and accounting obstacles prevent using target costing system."

\section{Methods}

\subsection{Population and Sample}

The researcher used the descriptive analytical approach in data collection and hypotheses testing, by distributing a questionnaire on financial managers, since they are the most suitable for answering questions regarding target costing or referring the matter to other more familiar with the subject. Fifty questionnaires were distributed, of which 43 were returned and only 35 were considered for analysis after 8 questionnaires were excluded due to blank responses to some items. The questionnaire included 26 items as follows:

\subsection{Instrumentation}

-To test the first hypothesis (possibility of applying target costing) items 1-9 of the questionnaire were developed as follows: (1- The management is always committed to maintaining and developing machinery, 2- The management prioritizes the quality of products, 3- Procurement Department personnel enjoy high levels of experience and competency, 4- Marketing Department personnel enjoy high levels of experience and competency, 5- Cost Management Department personnel enjoy high levels of experience and competency, 6- Financial Department personnel enjoy high levels of experience and competency, 7- Engineering Department personnel 
enjoy high levels of experience and competency, 8 - The company assesses its competitive advantage from time to time, 9- The company management is facing fierce competition) as shown in Table 1.

-To test the second hypothesis (cost reduction methods) items 1-9 of the questionnaire were developed as follows: (1- Creates a balance between required services and required products, 2- Develops performance, 3- Seeks to locate and eliminate dissipation, 4- Negotiates with suppliers over the prices of purchased materials, 5- The management is facing fierce competition, 6- Avoids faults and errors and maintains machines before production, 7- Maintains a balance between personnel numbers and duties, 8- Eliminates all pointless efforts) as shown in Table 2.

-To test the third hypothesis (obstacles to applying target costing application) items 18-26 of the questionnaire were developed as follows: (1- The management does not feel the necessity to apply target costing, 2- The unavailability of supporting systems to determine target costs whether for pricing or research and development, 3Measurement systems are traditional and do not belong to the modern age, 4- Lack of computer skills, 5Competition strategies are not applied, 6- dependence is rather on the human element than the technological element, 7- unavailability of data required for the application of the system, 8-Complex documentation and filing procedures, 9- Increased costs for applying target costing system) as shown in Table 3.

The following is a display of the results of statistical analysis of data, taking into consideration that responses were scaled as follows: strongly agree (5), agree (4), neutral (3), disagree (2), strongly disagree (1). Accordingly, the mean values of responses will be used to interpret data as follows:

\begin{tabular}{lcc}
\hline High & Medium & Low \\
\hline 3.5 and above & $2.5-3.49$ & $1-2.49$ \\
\hline
\end{tabular}

\subsection{Statistical Treatment}

To analyze data gathered by study variables, the statistical methods used included:

Means and standard deviations to identify extent to which respondents responded to instrument items

\section{Results and Discussions}

Based on data analysis and hypotheses testing.

\section{Hypothesis no. 1: Jordanian industrial firms are incapable of applying target costing.}

The analysis of items relevant to this hypothesis (1-9) (Table 1) shows that the mean of respondent think that there is a possibility for Jordanian industrial companies to apply target costing was between $3.28-4.12$, while the average total was 3.64 at a deviation of 0.42 with (high) rating.

Table 1. Arithmetic means and standard deviations of the paragraphs that measure the possibility of applying target costing

\begin{tabular}{|c|c|c|c|c|c|}
\hline Number & Paragraph & Mean & $\begin{array}{l}\text { Standard } \\
\text { Deviation }\end{array}$ & Rank & $\begin{array}{c}\text { Evaluation } \\
\text { degree }\end{array}$ \\
\hline 1 & $\begin{array}{l}\text { The management is always committed to } \\
\text { maintaining and developing machinery }\end{array}$ & 4.12 & 0.88 & 1 & High \\
\hline 2 & $\begin{array}{l}\text { The management prioritizes the quality of } \\
\text { products }\end{array}$ & 3.28 & 0.74 & 8 & High \\
\hline 3 & $\begin{array}{l}\text { Procurement Department personnel enjoy high } \\
\text { levels of experience and competency }\end{array}$ & 3.64 & 0.91 & 5 & High \\
\hline 4 & $\begin{array}{l}\text { Marketing Department personnel enjoy high } \\
\text { levels of experience and competency }\end{array}$ & 3.72 & 0.94 & 3 & High \\
\hline 5 & $\begin{array}{l}\text { Cost Management Department personnel enjoy } \\
\text { high levels of experience and competency }\end{array}$ & 3.40 & 1.08 & 6 & Moderate \\
\hline
\end{tabular}




\begin{tabular}{lllllll}
\hline 6 & $\begin{array}{l}\text { Financial Department personnel enjoy high levels } \\
\text { of experience and competency }\end{array}$ & 3.40 & 0.65 & 6 & Moderate \\
7 & $\begin{array}{l}\text { Engineering Department personnel enjoy high } \\
\text { levels of experience and competency }\end{array}$ & 3.36 & 0.76 & 7 & Moderate \\
8 & $\begin{array}{l}\text { The company assesses its competitive advantage } \\
\text { from time to time } \\
9\end{array}$ & $\begin{array}{l}\text { The company management is facing fierce } \\
\text { competition }\end{array}$ & 4.12 & 0.68 & 4 & High \\
\hline
\end{tabular}

The T- value for the capability of Jordanian industrial firms to apply target costing was 7.60 (Table 2 ), a statistically significant value at $a=0.05$ for the five-point rating scale and a standard average deviation of 3 . The domain mean average was 3.64 with (high) rating. This shows that there is a statistically significant correlation at $a=0.05$ for the capability of Jordanian industrial firms to apply target costing.

Table 2. Test (one- sample-T- test) to detect the possibility of applying target costing

\begin{tabular}{cccccc}
\hline Variable Arithmetic & Mean & $\begin{array}{c}\text { Standard } \\
\text { Deviation }\end{array}$ & T-Value & Freedom Degrees & $\begin{array}{c}\text { Statistical } \\
\text { significance }\end{array}$ \\
\hline possibility of applying target costing & 3.64 & 0.42 & 7.6 & 34 & 0.00 \\
\hline
\end{tabular}

\section{Hypothesis no. 2: Jordanian industrial firms do not use cost reduction methods.}

The analysis of items relevant to this hypothesis (10-17) (Table 3) shows that the mean for Jordanian industrial companies to apply cost reduction methods was between 3.08- 3.48, while the average total was 3.34 at a deviation of 0.46 with (high) rating.

Table 3. Arithmetic means and standard deviations of the paragraphs that measure the companies policies in applying cost reduction methods

\begin{tabular}{|c|c|c|c|c|c|}
\hline Number & Paragraph & Mean & $\begin{array}{l}\text { Standard } \\
\text { Deviation }\end{array}$ & Rank & $\begin{array}{c}\text { Evaluation } \\
\text { degree }\end{array}$ \\
\hline 1 & $\begin{array}{l}\text { Creates a balance between required services and } \\
\text { required products. }\end{array}$ & 3.40 & 1.26 & 3 & High \\
\hline 2 & Develops performance & 3.28 & 0.98 & 6 & High \\
\hline 3 & Seeks to locate and eliminate dissipation & 3.08 & 1.00 & 7 & High \\
\hline 4 & $\begin{array}{l}\text { Negotiates with suppliers over the prices of } \\
\text { purchased materials }\end{array}$ & 3.32 & 0.99 & 5 & High \\
\hline 5 & The management is facing fierce competition & 3.36 & 0.95 & 4 & Moderate \\
\hline 6 & $\begin{array}{l}\text { Avoids faults and errors and maintains machines } \\
\text { before production }\end{array}$ & 3.48 & 0.77 & 1 & Moderate \\
\hline 7 & $\begin{array}{l}\text { Maintains a balance between personnel numbers } \\
\text { and duties }\end{array}$ & 3.44 & 0.96 & 2 & Moderate \\
\hline 8 & Eliminates all pointless efforts & 3.36 & 1.38 & 4 & High \\
\hline
\end{tabular}

The $T$ value for applied cost reduction methods was 3.70 (Table 4), a statistically significant value at $a=0.05$ for the five-point rating scale and a standard average deviation of 3 . The domain mean average was 3.34 with (high) rating. This shows that Jordanian industrial firms apply cost reduction methods. 
Table 4. Test (one- sample-T- test) to detect the companies' policies in applying cost reduction methods

\begin{tabular}{lccccc}
\hline Variable Arithmetic & Mean & $\begin{array}{c}\text { Standard } \\
\text { Deviation }\end{array}$ & T-Value & Freedom Degrees & $\begin{array}{c}\text { Statistical } \\
\text { significance }\end{array}$ \\
\hline $\begin{array}{l}\text { the companies policies in applying cost } \\
\text { reduction methods }\end{array}$ & 3.64 & 0.46 & 3.70 & 34 & 0.01 \\
\hline
\end{tabular}

Hypothesis no. 3: Jordanian industrial firms do not face any substantial limitations and difficulties in organizational, managerial and accounting aspects, which hinder the application of target costing.

The analysis of items relevant to this hypothesis (18-26) (Table 5) shows that the mean limitations and difficulties facing Jordanian firms was between 3.36- 4.12, while the average total was 3.80 at a deviation of 0.91 with (high) rating.

Table 5. Arithmetic means and standard deviations of the paragraphs that measure the obstacles facing applying target costing system

\begin{tabular}{|c|c|c|c|c|c|}
\hline Number & Paragraph & Mean & $\begin{array}{l}\text { Standard } \\
\text { Deviation }\end{array}$ & Rank & $\begin{array}{c}\text { Evaluation } \\
\text { degree }\end{array}$ \\
\hline 1 & $\begin{array}{l}\text { The management does not feel the } \\
\text { necessity to apply target costing }\end{array}$ & 3.80 & 0.91 & 2 & High \\
\hline 2 & $\begin{array}{l}\text { unavailability of supporting systems to } \\
\text { determine target costs whether for pricing } \\
\text { or research and development }\end{array}$ & 3.48 & 1.05 & 5 & Moderate \\
\hline 3 & $\begin{array}{l}\text { Measurement systems are traditional and } \\
\text { do not belong to the modern age }\end{array}$ & 3.44 & 0.71 & 6 & Moderate \\
\hline 4 & Lack of computer skills & 3.36 & 0.76 & 7 & Moderate \\
\hline 5 & Competition strategies are not applied & 3.64 & 0.64 & 3 & High \\
\hline 6 & $\begin{array}{l}\text { dependence is rather on the human } \\
\text { element than the technological element }\end{array}$ & 4.12 & 0.44 & 1 & High \\
\hline 7 & $\begin{array}{l}\text { unavailability of data required for the } \\
\text { application of the system }\end{array}$ & 3.64 & 1.41 & 3 & High \\
\hline 8 & $\begin{array}{l}\text { Complex documentation and filing } \\
\text { procedures }\end{array}$ & 3.36 & 0.95 & 7 & Moderate \\
\hline 9 & $\begin{array}{l}\text { Increased costs for applying target costing } \\
\text { system }\end{array}$ & 3.61 & 0.42 & 4 & High \\
\hline
\end{tabular}

The $t$ value for limitations and difficulties of applying target costing was 7.20 (Table 6), a statistically significant value at $\boldsymbol{a}=0.05$ for the five-point rating scale and a standard average deviation of 3 . The domain mean average was 3.80 with (high) rating.

Table 6. Test (one- sample-T- test) to detect the obstacles facing applying target costing system

\begin{tabular}{lccccc}
\hline Variable Arithmetic & Mean & $\begin{array}{c}\text { Standard } \\
\text { Deviation }\end{array}$ & T-Value & Freedom Degrees & $\begin{array}{c}\text { Statistical } \\
\text { significance }\end{array}$ \\
\hline $\begin{array}{l}\text { The obstacles facing applying target } \\
\text { costing system }\end{array}$ & 3.80 & 0.91 & 7.2 & 34 & 0.00 \\
\hline
\end{tabular}




\section{Conclusion}

So the study has concluded that industrial firms have the potential and the capability to apply target costing, at an average with (high) rating. This could be attributed to management's interest in maintaining and developing machinery as well as fierce competition which highlight the need for the application of target costing. The study also found that Jordanian firms are applying cost reduction methods, at an average of with (high) rating. This could be attributed to avoiding errors and faults, maintaining machines before production and creating a balance between the number of personnel and their duties. The study also found that there are substantial limitations and difficulties which hinder the application of target costing, at an average of with (high) rating. This could be attributed to various difficulties facing Jordanian companies such as depending on the human element rather than the technological element and the lack of computer skills.

According to the aforementioned results, the study recommends the integrated application of target costing in industrial firms, and calls on industrial firms to eliminate the difficulties which hinder the application of target costing, as well as holding courses for company personnel to train them on designing and applying the target costing method.

\section{References}

Ansari, S., \& Bell, J. (1997). Target Cost Core Group, Target Costing: The Next Frontier in Strategic Cost Management, Consortium for Advanced Manufacturing International.

Bear, R., Mills., \& Schmid, F. (1994). Product Costing In Advanced Technology Environments. Management Accounting. http://dx.doi.org/10.1016/S0925-5273(02)00450-4

Boer, G., \& Ettlie, J. (1992). Target Costing Can Boost Your Bottom-Line. Management Accounting, 81(1), 49-52.

Borgemas, H., \& Fridh, G. (2003). The use of target costing in Swedish manufacturing firms. Goteborg University, school of economics \& commercial law.

Cooper, R., \& Slagmudler, R. (2002). Target costing for new-product development: Product level target costing. Journal of cost management.

Cooper, R., \& Slagmulder, R. (1999). Develop Profitable New Product with Target Costing. Sloan Management Review, 40(4).

Dekker, H., \& Smidt, P. (2003). A survey of the adoption and use of target costing in Dutch firms. International Journal of production economic, 84.

Horngren, T. G., Sundem, L .G., \& Stratton, O.W. (1997). Introduction to Management Accounting $\left(10^{\text {th }}\right.$ edition). prentice-Hall, Inc.1070.

Ibusuki, U., \& Kaminski, P. (2007). Product development process with focus on value engineering target costing: a case study in an automotive company. International Journal of production Economics, 105(2), 459-474. http://dx.doi.org/10.1016/j.ijpe.2005.08.009

Kaplan, R. S., \& Atkinson, A. A. (1997). Advanced Management Accounting ( ${ }^{\text {rd }}$ edition). Prentice-Hall international, Inc.

Kato, Y. (1993). Target Costing Support System: Lessons from Leading Japanese Companies. Management Accounting Research, 4(1), 33. http://dx.doi.org/10.1006/mare.1993.1002

Keun-Hyo, Yook. (2005). Target costing the construction industry: evidence from Japan, construction accounting $\&$ taxation.

Lockamy, A., \& Smith, W. I. (2000). Target Costing For Supply Chain Management: Criteria and Selection. International Management \& Data Systems, 100(5).

Pierce, B. (2002). Target costing management Comprehensive Benchmarking for a competitive market. Accountancy, 34.

Swenson, Dan. et. (2003). Best practices in target costing. Management accounting quarterly, 12-32.

Wood, J. (1995). First Annual International Congress on Target Costing. Management Accounting, 79(7), 63. 